\title{
School vs Industry A Relation of Competencies and Skills
}

\author{
http://dx.doi.org/10.3991/ijep.v2i4.2296 \\ V. Bristot ${ }^{1}$, V. Bristot ${ }^{2}$, L. Schaeffer ${ }^{3}$, V. Gruber ${ }^{4}$, R. Marcelino ${ }^{4}$, J. B. da Silva ${ }^{4}$ \\ ${ }^{1}$ Instituto Maximiliano Gaidzinski - IMG, Cocal do Sul, Brasil \\ ${ }^{2}$ Eliane Revestimentos Cerâmicos S.A, Cocal do Sul, Brasil \\ ${ }^{3}$ Universidade Federal do Rio Grande do Sul - UFRGS, Porto Alegre, Brasil \\ ${ }^{4}$ Universidade Federal de Santa Catarina - UFSC, Araranguá, Brasil
}

\begin{abstract}
This paper presents a set of initiatives that were developed in the area of educational management in a technical school, vocational whose sponsor industry-shaping ceramic tiles. These initiatives were based on the development and implementation of an educational model that has the distinction of a new evaluation methodology based on the concepts of values (personal skills and abilities, relational, cognitive and productive). To this end, the research explores the quality of management and industrial and educational profile of students who graduated with this new type of management. The validation of this educational model occurred from an environmental analysis in the institutions involved, based on a step of collecting perceptual data and a second stage of data collection evident. Through this analysis, there was a qualitative leap of the people involved, because this model showed an improvement in the socio-educational school community and especially the relationship with the student's school and especially with the industry. It was also found that the differential of this new model of management education was to prepare the student still at school for the challenges that await you at the in the industrial sector, because this type of management has as main purpose the formation of people of excellence.
\end{abstract}

Index Terms-Competencies and skill, Educational and industrial management, Education in the industry

\section{INTRODUCTION}

It is a fact that education is currently undergoing profound changes, especially school educational management. This management is a determining factor of quality of performance by the school and its students, above all insofar as it increases the decentralization of the decision processes in the educational systems.

In recent years, educational planning has privileged two major themes of research: quality of teaching and educational management. In both cases, although discussions are nothing new, it was only in the 1990s that they acquired an outstanding dimension. Experience has shown that a quality education cannot be obtained in educational systems and schools with slow centralizing bureaucracies, excessively concerned with rules and regulations, and with a hierarchical structure that does not give them any flexibility to solve problems.

It is now known that school does make a difference in the students' performance, and that it must be appropriately managed to meet its objectives. There is strong evidence that management is a decisive component of school efficacy. Many studies, in Brazil and abroad, have proved that well run and organized schools are more effective [1].

Currently, it is common to encounter young people seeking inclusion in the labor market direction for education. However, it is also common to find employers who say that schools do not prepare for the world of work, as young people leave with the same basic needs in terms of training [2].

It is in this sense that this paper proposes a new educational model based on personal competencies and skills, focusing on quality management applied to industry.

\section{COMPETENCIES AND SKILLS}

The difference between competency and skill, in a first approach, depends on what part one is dealing with. Problem-solving, for instance, is a competency that assumes that one has mastered several skills. Calculating, reading, interpreting, making decisions, answering in writing, etc. are examples of skills needed to solve arithmetic problems. In other words, competency is a general skill, while skill is a particular and specific competency [3].

The essential structures of the educational process and school organization are connected around the importance of the conception of the subject to solve problemsituations of daily life involving different degrees of complexity. It is in these situations that the student will begin to exercise skills and competencies through the contents.

For this to happen, teaching aims at providing opportunities for changes that will trigger cognitive, affective and social development. When we mobilize knowledge, values and attitudes, acting pertinently to solve problem situations, we have what we call competency. When we make a decision to solve problems, often we improvise and use creativity associated with experience.

Schooling is a choice of society, and should also be founded on broad, up to date knowledge of social practices, since school reproduces society.

In a schooling process, besides constructing and reconstructing knowledges, when developing competencies and skills there is a need to dedicate time to put them into practice. The students construct knowledges, pass the entrance exams to university, but do not manage to mobilize the knowledge to apply it to daily situations.

The concept of competency is closely related to the idea of laborability and increases the responsibility of teaching institutions to organize the curriculums and methodologies that broaden capacities such as solving new problems, 
PAPER

communicating ideas, making decisions. Competency is a set of knowledges and skill; it is a knowing-how-to-do related to work practice, more than mere motor action. The skills are essential for action, but require mastery of knowledge. Education for competencies will be performed through contextualization and interdisciplinarity, with contents pertaining to the student's reality [4].

\section{Methodology For EVALUATION BY COMPETENCIES AND SKILLS}

Every day, more companies understand that the issue competency management should be worked, and with urgency in organizations [5].

The system to evaluate performance by competencies and skills is very useful for the industries that apply or intend to apply this kind of management. The purpose of this concept is to develop its employees, and it can be seen that there is a possibility of systematizing and clarifying the progression of people in their jobs, as well as a base to increment the quality of the services provided.

In order to achieve these purposes, in their strategic planning industries define the values that their employees should follow, i.e., what are their principles or beliefs, used as a guide or criterion for behaviors, attitudes and decisions.

The idea of this study is to apply these industrial concepts to the school setting, in order to prepare the student for the reality that awaits them in industry.

These values which we call competencies and skills, used to evaluate the students, were defined by the pedagogical department of the school together with the company human resources department. Eight (8) competencies were defined: Technical Knowledge, Ethics and Trust, Responsibility, Education/Relationship, Leadership, Verbal and Written Communication, Participation/Interest and Initiative. These competencies are strongly connected to the strategy of industrial management, ie., values that represent what the companies need and expect from an excellent employee.

After these performance values were defined (competencies and skills), a management model was developed for evaluation also by competency in school, which, together with the traditional performance of schools which are the cognitive grades (from the School report card), may develop a system to measure competencies and skills constructed using the behavioral and intellectual inventory.

As to the methodology applied, the study is characterized as to its ends as: qualitative, descriptive and applied. As to the classification of the means, the following is proposed: documents, bibliography and case study. Data were analyzed by establishing relations between analysis of documents, information obtained in interviews and researcher's observation, correlating them with the theory.

In the first stage of this process, all teachers at the institution received a form to evaluate competencies (see Table 1) containing the name of the studies and the competencies and skills that were defined as mentioned previously.

Each teacher, during the semester, follows the students in their classes, taking notes and giving a score of 1 to 10 to each item described and their due observation.
At the end of the semester, the teacher hands the completed form to the pedagogical department. They then tabulate all scores and observations mentioned by the teachers.

\section{EXPERIMENTAL PROCEDURE}

A school that adopted this practice in its political pedagogical plan was chosen to apply this educational model. The institution chosen was Colégio Maximiliano Gaidzinski - CMG, belonging to Instituto Maximiliano Gaidzinski - IMG, in the municipality of Cocal do Sul, state of Santa Catarina. This school has trained ceramics and electro mechanics technicians since it was founded in 1979.

A company that had former CMG students among its employees was chosen to evaluate and spell out the benefits of this model in industry. The company chosen was Eliane Revestimentos Cerâmicos, a family-owned company that opened in 1960 and is one of the largest ceramic tile manufacturers in the world.

The method proposed and used for this evaluation in industry was to look at the same aspects of competencies and skills performed by the teachers in the classroom, i.e., the competency evaluation form were used.

This form (see Table II) was sent to the supervisors (coordinators) of the company where these former students work, and they were able to compare the CMG graduates using this new educational model to people who had graduated from another school.

TABLE I.

TEACHER'S FORM FOR EVALUATION OF COMPETENCIES

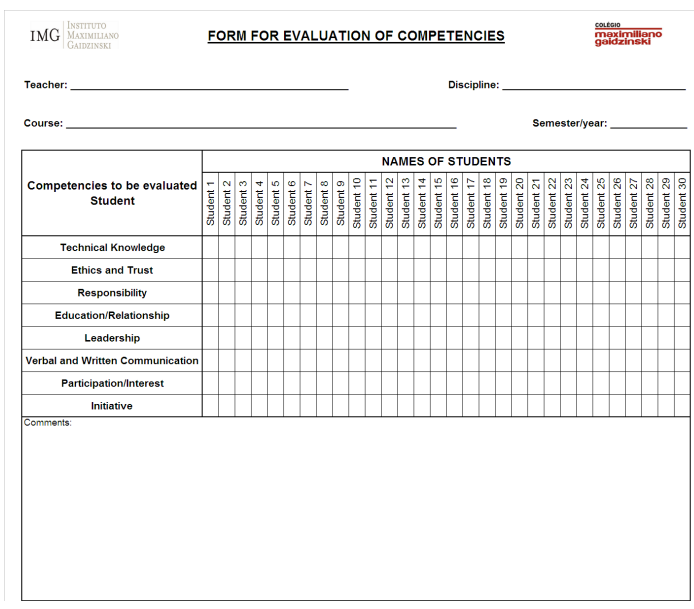

TABLE II.

FORM FOR EVALUATION OF COMPETENCIES IN INDUSTRY

\begin{tabular}{|l|l|l|}
\hline \multirow{2}{*}{ Competencies to be evaluated } & \multicolumn{2}{|c|}{ SCOREs (1 1 10) } \\
\cline { 2 - 3 } & Graduate of $\mathrm{CMG}$ & $\begin{array}{c}\text { Graduate of } \\
\text { another instrution }\end{array}$ \\
\hline 1 - Technical Knowledge & & \\
\hline 2 - Ethics and Trust & & \\
\hline 3 - Responsibility & & \\
\hline 4 - Education/Relationship & & \\
\hline 5 - Leadership & & \\
\hline 6 - Verbal and Written Communication & & \\
\hline 7 - Participation/Interest & & \\
\hline 8 - Initiative & & \\
\hline
\end{tabular}




\section{RESUlTS AND DisCUSSIONS}

Initially an analysis was performed in the school environment, based on the gathering perceptive data with students and teachers.

They observed that the evaluation model proposed allowed the student to know more about skills and how to do things, and to have a greater connection between himself and learning, the possibility of constructing his own knowledge and see it as a whole (capacities and values). It also allowed a personalized follow up of the interaction between the student's learning and the industry and society, and to know how to manage knowledge beyond the school space, and to make decisions using the information acquired, besides preparing the student for life.

It was also found that this form of evaluation allowed the teacher to see the student's problems and help him overcome them, solidifying his knowledge, with greater fairness, and giving the teacher a clearer idea of the individuals' aptitudes in various fields.

During the second stage, the competencies and skills of the former students were analyzed in the industrial setting, based on a field research (Graph 1).

It was seen that the students who had graduated from $\mathrm{CMG}$ in all competencies required had higher scores than the students who had attended another institution. This difference is, on average around $20 \%$, and the competencies evaluated using the more different indices are technical knowledge and verbal and written communication.

\section{CONCLUSION}

Thinking about the conditions of professional reality and concerned with the human training of the student on the work market, it was found necessary to create and approach the values required to develop the competencies and skills for success in a future professional career. Considering this context and following the changes occurring in the job market, the school, Colégio Maximiliano Gaidzinski, aimed to expand and improve its work in pedagogical activities.

The purpose of this study was to gain a better understanding of how a management model is formed. It was found that the definition of competencies and skills for the students was of utmost importance to organize the activities, and these characteristics are directly related to the result within the companies.

This also led to an improvement in the relationship between school and industry, and also between school and society itself, because this model allowed a broader evaluation, making it possible to assess student's knowledge and knowing how to do things, their information, aptitudes, imagination, opinions, their and their different capacities in distinct areas.

It is in this sense that the development of the activities proposed in this paper, by creating a new model of educational management, presented a great qualitative leap forward in activities, both of the school and of the industry, consolidating the efforts of the entire team involved, who seek, above all, to educate people of excellence.

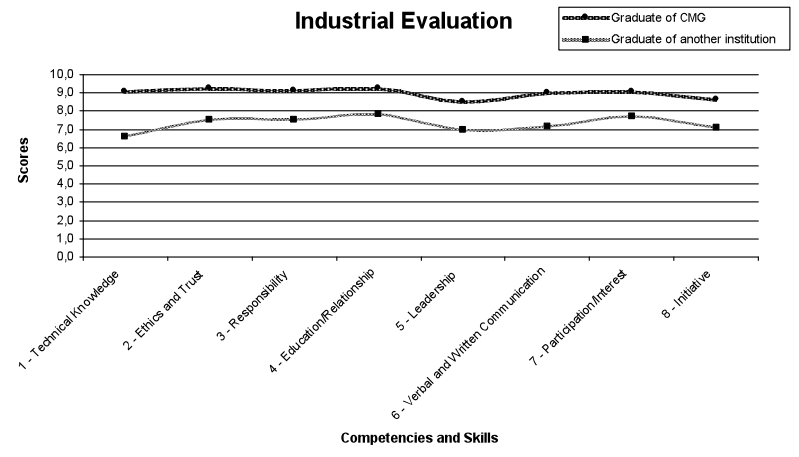

Graph 1. Result of the Industrial Evaluation

\section{REFERENCES}

[1] A.C.R. Xavier, "A Gestão da Qualidade e a Excelência dos Serviços Educacionais: Custos e Benefícios de sua Implantação", Texto para discussão n. 408, IPEA, Brasília, 1996.

[2] N. L. Franzoi, I.L.S. Correa, A.C.F. Godinho, C. Parenza, "Trabalho, trabalhadores e educação: conjunturas e reflexões", Editora Evangraf. UFRGS - Porto Alegre, 2010.

[3] L. Macedo, Ensaios construtivistas. 4. ed. Casa do Psicólogo, 170 p. São Paulo, 1999,

[4] P. Perrenoud, Dez Novas Competências para Ensinar, Artmed Editora, Porto Alegre, 2000.

[5] R. Leme, "Aplicação prática de gestão de pessoas por competências: mapeamento, treinamento, seleção, avaliação e mensuração de resultados de treinamento", Qualitymark Editora. 224 p, Rio de Janeiro, 2012.

[6] C.Viegas, A. Marques, G.R. Alves, C.C. Lobo, "Engaging students by Moodleing a Course? Case studies at the Polytechnic of Porto - School of Engineering". International Journal of Engineering Pedagogy (iJEP), Vol 2, No 3 (2012).

[7] J.B. Silva, V. Gruber, R. Marcelino, "New Technologies for Information and Communication, PWM Remote Experimenting and $3 G$ Networks as Teaching Support”. International Journal of Engineering Pedagogy (iJEP), Vol 2, No 1 http://dx.doi.org/10.3991/ijep.v2i1.1908

\section{AUTHORS}

V. Bristot is with the Instituto Maximiliano Gaidzinski - IMG, CEP 88845-000, Cocal do Sul, SC, Brasil - phone: 55483447 7736; (e-mail: vilmar.bristot@imgnet.org.br)

V. Bristot is with the Eliane Revestimentos Cerâmicos S.A, CEP 88845-000, Cocal do Sul, SC, Brasil - phone: 55 483447 7757; (e-mail: vilson.bristot@eliane.com)

L. Schaeffer is with the Centro de Tecnologia, Escola de Engenharia, Universidade Federal do Rio Grande do Sul - UFRGS, CEP 91501-970, Porto Alegre, RS, Brasil; (email: schaefer@ufrgs.br)

J. B. da Silva, R. Marcelino and V. Gruber is with the Universidade Federal de Santa Catarina-UFSC, Campus Ararángua, SC, Brasil; (e-mail: juarez.silva@ieee.org;roderval.marcelino@reitoria.ufsc.br ; vilson.gruber@ufsc.br)

Received October $1^{\text {st }}, 2012$. Published as resubmitted by the authors Ocober $5^{\text {th }}, 2012$. 